\title{
Features of the underground storages construction in depleted oil and gas condensate fields
}

\author{
Ramiz A. GASUMOV ${ }^{1}$, Eldar R. GASUMOV ${ }^{2}$, Julia S. MINCHENKO ${ }^{1}$ \\ ${ }^{1}$ JSC «SevCavNIPIgaz», Stavropol, Russia \\ ${ }^{2}$ Azerbaijan State Oil Academy, Baku, Azerbaijan
}

How to cite this article: Gasumov R.A., Gasumov E.R., Minchenko Yu.S. Features of the underground storages construction in depleted oil and gas condensate fields. Journal of Mining Institute. 2020. Vol. 244, p. 418-427. DOI: 10.31897/PMI.2020.4.4

\begin{abstract}
The paper considers the features of the underground storages (US) construction in depleted oil and gas condensate fields (DOGCFs). The requirements for the structure of the formation, corresponding to the parameters of the object for possible US creation are presented.

The influence of geological, hydrogeological, mining and technical rock formation conditions on the reliability and tightness of underground storages, including underground gas storages, has been evaluated. The necessary conditions for the US design are analyzed at the example of the Ach-Su oil and gas condensate field, in the presence of a wellexplored trap with acceptable parameters for the construction of an underground storage. An important aspect is the geological conditions that meet the criteria for selecting the object: the required structure, the absence of fracturing faults, high reservoir properties of the formation, a sufficient volume of the deposit for the storage. Geological conditions lay the basis for determining the individual characteristics of the US construction technology at each DOGCF. The refined results for the current gas-saturated pore volume and the rate of pressure drop in the formation are presented, which makes it possible to select improved technological indicators in the course of operation of the created US. In order to select the optimal option for the design and construction of the US, the results of economic and geological scenarios analysis were studied concurrently with the capabilities of the technological operation of the object and transport system, which can ensure the maximum daily production of the storage.
\end{abstract}

Key words: formation structure; geological conditions; underground storage; depleted oil and gas condensate fields; design; traps; permeability and porosity properties; formation-reservoir; injected product

Introduction. The peculiarity of creating underground storages (US) is that the pore space in the formation of a depleted oil and gas condensate field (DOGCF) is used as a tanker for storing the injected product. This formation must have a considerable capacity and be economical and safe for the environment at a sufficiently high pressure level. In this regard, it is necessary to study the productive formation with an appropriate geological structure (usually domed), capable of storing the injected product, as well as a sealed cap in the created facility [10]. These parameters designate the geometrical volume of a single reservoir, the maximum and minimum working pressure of the product in the US, the volume of the active mass, i.e. basic conditions for the possibility of creating an underground storage. The article presents the results of assessing the suitability of rocks for creating USs using the results of studying the properties of rock formations in which an underground storage is built.

Statement of the problem. Geologically, the structure of the formation should have cavities corresponding to the parameters required for the object of possible US creation. A prerequisite for the design of an object is the presence of a well-studied trap with acceptable parameters for the construction of US [3].

Depleted deposits are preferable to use in order to create a US based on geological parameters; in addition, economic, technical, technological, environmental, social, regional and other factors should be taken into account $[5,11]$.

Methodology. Research methods comprised the analysis and generalization of information on the structure of mining, geological and hydrodynamic characteristics of the formation (at the example of minor gas condensate fields); the sources and nature of water cut were considered based on 
the study of analytical relationships between formation pressure in the hydrodynamic system, volumes of hydrocarbon (HC) recovery and the amount of incoming formation fluid from the edge water zone. Field data, the results of analytical and experimental investigations carried out at the wells of the Ach-Su oil and gas condensate field and in laboratory conditions were used.

The main indicators of the physical and mechanical properties of the rocks, i.e., their durability characteristics and rheological features, have been studied. Ultimate resistances to elementary types of stresses, i.e., uniaxial compression, strain, shear and bending, were used as the durability characteristics. The rocks suitable for the construction of underground storages, distinguished by their high plasticity, i.e., the ability to undergo irreversible deformations, have been identified.

Discussion. A distinctive feature of the US construction process in depleted oil and gas condensate fields is that no study of permeability and porosity properties is carried out in the process of developing a productive deposit due to the sufficient amount of data on the geological field material acquired. The main investigations in the US creation in a DOGCF are related to the study of the technical condition of the existing wells. Not every depleted oil and gas field can be used as a structure for creating a US, for example, the main feature of the possibility of creating an underground gas storage is the presence of a gas cap, i.e., free gas at the top of the structure. Depending on the aim of the US to be constructed, each storage should be individual and depend on many factors; based on its purpose, special requirements are imposed on it [13].

The geological indicators of a DOGCF, i.e., physical properties of the reservoir, the degree of its homogeneity, the presence of tectonic disturbances, the state of the formation water activity, are decisive when selecting the optimal ways to create a US and predetermine its operational efficiency [7].

It is important that the reservoir had the required thickness, lithological homogeneity, and optimal reservoir properties. When creating an object, high reservoir properties of the reservoir (permeability, porosity) with low heterogeneity of rocks allow optimizing the number of production and observation wells, controlling the introduction of formation waters during a US operation [4, 6]. It is difficult to draw conclusions from geological and hydrodynamic data in the presence of faults, overthrusts and other changes in the reservoir. In addition, tectonic disturbances cause problems in ensuring the tightness of the US. The depth of the formation and its physical parameters (density, durability and plasticity of the roof) significantly affect the maximum allowable pressure in the US.

The method of the US creation and the rate of the product injection, maximum injection pressure of the units selected for the pumping and extraction of gas from the US, also affect the maximum allowable pressure in the storage: the lower the rate of pressure increase, the higher can be the increase in the pressure in the US [8].

The main feature of the hydrocarbon fuels in US is their long-term direct contact with the host rock, in which the tanker is being built. In the US, in contrast to above-ground storage tanks, the storage temperature of the product does not particularly depend on natural and climatic conditions, seasonal fluctuations in air temperature, and the top layer of the soil. Seasonal extraction of hydrocarbon fuel has the maximum effect on the US operation (it can lead to changes in the technological regime) and, accordingly, on the operation of the vessel itself.

The assessment should be carried out in the process of studying properties of the rock suitability for the creation of a US, taking into account the range of rocks in which it is recommended to build the US. These include almost all impermeable rocks: sedimentary, igneous and metamorphic. Such rocks should also have great plasticity, i.e., the ability to undergo irreversible deformations.

Consideration of rheological phenomena in the rocks prone to plastic deformation is of particular importance in mining and technical calculations of US. The volume stability should be determined by the long-term durability of rocks taking into account their creep and relaxation. Thus, carrying out integrated research of the rock properties will make it possible to assess correctly their suitability for the construction of the US [2]. 
Let us consider this approach using the example of a specific DOGCF Ach-Su, the structure of which has a typical brachyanticline, longitudinal and squeezed from the sides. In the chalk sediments, the brachyanticline has an almost symmetrical structure. The incidence angles on the wings of the structure are $18-25^{\circ}$ and $3-12^{\circ}$ on the periclines. Along the closing isohypse of $3400 \mathrm{~m}$, the structure has dimensions of $16.0 \times 2.0 \mathrm{~km}$ and an amplitude of about $380 \mathrm{~m}$. The large longitudinal fissures registered by a seismic survey additionally put a strain on the wings of the structure. The southwest wing is steeper and borders the syncline through a dislocation, which has an amplitude of $600 \mathrm{~m}$. This syncline is open to the southeast and is limited by dislocations.

The arch of the Cretaceous structure is located under the northeastern flank of the Miocene structure. The discrepancy between the arches of the DOGCF structure in its lower and upper structural plans is seen quite clearly. The displacement value in the highest part amounts to $2-2.5 \mathrm{~km}$.

The Upper Cretaceous deposit of the DOGCF belongs to the massive type and is confined to the carbonate stratum, composed of dense limestones with interseams of marls and highly calcareous clays. Limestones are cavernous to varying degrees. The average value of the cavernosity coefficient amounted to $2 \%$. Increased cavernosity is confined to the roof part of the Upper Cretaceous. Porosity values when calculating reserves are taken in the amount of 0.01 fraction units and gas saturation of 0.8 fraction units.

Industrial oil and gas content of the field is associated with sandstones of the Chokrakan Neogene and foraminiferous layers of the Paleogene, to which oil deposits are confined, and carbonate deposits of the Upper Cretaceous, containing a gas condensate deposit. The most capacious reservoirs in the field are the Upper Cretaceous deposits, the insufficient knowledge of which does not allow speaking about certain patterns of changes in their lithofacies characteristics.

The depth of the gas-containing interval amounts to $3120-3285 \mathrm{~m}$. The deposit altitude is 165 $\mathrm{m}$. The initial gas-water contact (GWC) was located at a depth of 3,275 m. Indications of oil obtained near the GWC pointed to the presence of a minor (up to $3 \mathrm{~m}$ ) oil rim of non-industrial worth. The initial formation pressure, reduced to the middle of the formation stage, is $42.2 \mathrm{MPa}$ and the formation temperature is $130{ }^{\circ} \mathrm{C}$. The deposit is characterized by a rapid decrease in formation pressure during well operation. The formation is in gas mode.

Twenty wells have been drilled within the field on the gas condensate deposit in the Upper Cretaceous sediments of the DOGCF. The initial GWC was set at the mark of 3,275 m. The highest gas production rates were obtained in the wells located in the central part of the deposit, while the smallest ones were registered in the wells located in the northwestern part. At the same time, no inflow was obtained in the well drilled within the northwestern pericline of the Upper Cretaceous fold, which indicates the loss of reservoir properties by the containing sediments in this part of the deposit.

Production drilling has not been carried out at the field, and the development of the Upper Cretaceous deposit was performed only by exploration wells.

Gas reserves of the DOGCF have been repeatedly identified by the volumetric method and by the method of formation pressure drop at various stages. The large scatter in values for reserves is due to the insufficient degree of study on the capacitive properties of the productive formation of the Upper Cretaceous sediments, composed of cavernous and porous limestones.

Figure 1 shows the dynamics of changes in the actual formation pressure in the deposit. As it can be seen from Fig.1, the last measurement point of the formation pressure for the well lies significantly above the pressure decrease line during the deposit development. In total, more than 1.2 billion $\mathrm{m}^{3}$ of gas was withdrawn from the deposit, the condensate equivalent taken into account. This value is the limiting value for gas injection into the formation when creating a storage at this stage of exploration maturity. The expected rate of decline (growth) of the formation pressure during the US creation is determined by the actual dependence of the reduced formation pressure on the accumulated gas extraction (Fig.2). 


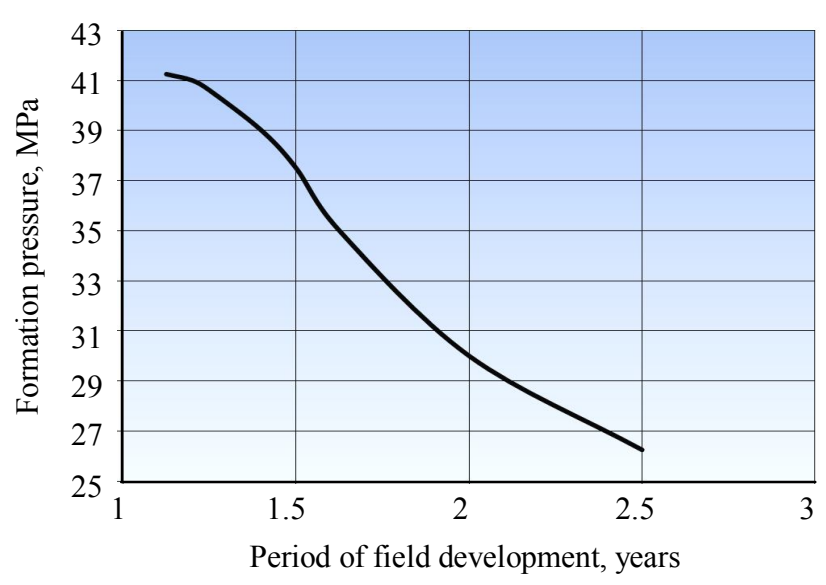

Fig.1. Dynamics of the actual formation pressure at DOGCF



Fig.2. Dependence of the reduced formation pressure on accumulated gas extraction

The total amount of gas in the reservoir is assumed to be equal to the volume of uneven gas consumption, based on the ability of the deposit to contain the injected gas. Options for creating a US for gas accumulation in a DOGCF differ in the amount of buffer gas. Different amounts of buffer gas determine the options for UGS operation with the estimated values of the pore space, insufficient knowledge of the water pumping system impact on the operation of the storage, and the dynamics of the formation pressure drop.

Table 1 shows the change in well productivity based on the results of gas hydrodynamic investigations of wells (GHIW). The study of the ratio between "formation pressure" and "well flow rate" parameters shows that a decrease in pressure to $35 \mathrm{MPa}$ leads to a significant decrease in gas flow rate.

Table 1

Change in well productivity at a DOGCF (based on the results of GHIW)

\begin{tabular}{c|c|c|c|c}
\hline \multirow{2}{*}{ Well N } & \multicolumn{2}{|c|}{ Pressure, MPa } & Pressure drop, MPa & $\begin{array}{c}\text { Gas flow rate, thousand, } \\
\mathrm{m}^{3} / \text { day }\end{array}$ \\
\cline { 2 - 3 } & Formation & Bottomhole & & \\
\hline 1 & 44.70 & $33.63 / 36.76^{*}$ & $7.94 / 11.07$ & $343.23 / 455.59$ \\
2 & 35.20 & $30.62 / 33.61$ & $1.59 / 4.58$ & $84.56 / 188.45$ \\
3 & 43.85 & $36.64 / 39.06$ & $4.79 / 7.21$ & $342.50 / 459.30$ \\
4 & 38.53 & $15.54 / 25.70$ & $12.83 / 22.99$ & $28.19 / 63.60$ \\
5 & 36.30 & $26.88 / 30.43$ & $5.87 / 9.42$ & $369.75 / 550.08$ \\
6 & 35.73 & $35.44 / 35.57$ & $0.16 / 0.28$ & $44.20 / 86.00$ \\
\hline
\end{tabular}

${ }^{*}$ Minimum / maximum value.

At the maximum daily productivity during the extraction period, the formation pressure in the storage varies from 41.4 to $36.5 \mathrm{MPa}$. The operation of the storage when the pressure drops to the level of the lower boundary affects the productivity of wells.

In the options under consideration, a process control system and an industrial waste disposal scheme are provided. Forecast of the main technological indicators of the US operation during its creation based on DOGCF:

Parameters

The total amount of gas in the reservoir, million $\mathrm{m}^{3}$ Active gas volume, million $\mathrm{m}^{3}$ Buffer gas volume, million $\mathrm{m}^{3}$ Maximum daily storage performance, million $\mathrm{m}^{3}$ Pressure at the start of the extraction, MPa Pressure at the end of the extraction, MPa Length of extraction period, days Number of production wells

$\begin{array}{cc}\text { Option } 1 & \text { Option } 2 \\ 1200 & 860 \\ 600 & 600 \\ 600 & 260 \\ 5.6 & 5.6 \\ 41.4 & 41.4 \\ 36.5 & 36.5 \\ 120 & 120 \\ 16 & 16\end{array}$




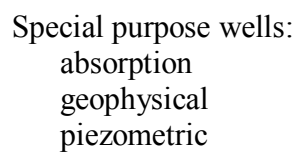

As a result of seismic surveys within the studied area, the reflecting horizon is conventionally assigned to the surface in the Eocene Upper Cretaceous sediments. Such stratification is due to the fact that the Eocene sediments are composed of high-velocity formations, the carbonate content of the rocks gradually increases from the Eocene to the Upper Cretaceous.

Despite the fact that the field has been in development for a long time, the structure of the pore space and the permeability and porosity characteristics of the reservoir have not been fully studied. A feature of the field is the atypical watering of wells located in the crest of the deposit. It is assumed that the reservoir in the top of the deposit has a branched network of vertical cracks.

The study of the rock samples made it possible to carry out a qualitative interpretation of GIW, to study the directions of cracks. Taking into account the basic patterns for cavernosity affecting the permeability and porosity properties of the reservoir is necessary for reliable forecasting, calculation of reserves, and development of hydrocarbon deposits. Information on the direction of the cracks will allow the development of the design of high-performance wells with complex profiles (inclined or horizontal) [14, 15]. Wave acoustic logging was used for lithological subdivision of rocks, identification of permeable intervals, and determination of the pore space structure. Direct methods of cavernosity research, which are the most reliable and informative among other methods, were used on the rock samples [1, 9, 12].

Changes in the lithological composition and structure of the formations, the presence of cracks and changes in porosity are clearly shown by electric micro scanning. The characteristics of micro cracks were studied using thin rock sections (optical microscopic method, method of capillary saturation of rocks with luminescent liquids). Macro cracks have developed selectively along a denser network of micro cracks and together with them constitute a single system subject to the general patterns of development. In laboratory conditions, the parameters of macro cracks were studied using a full-size rock sample.

The integrated approach, which includes at the general stage the results of aerospace geological research (ASGR) or seismic survey, information on the structures and tectonics of the region, and at the stage of detailing - the results of cavernosity research on oriented rock samples and well geophysics, provided for a reliable picture of the deformed rock state.

The aquifer of the formation " $G$ " of the Chokrak sediments in the depleted oil deposits of the field was considered as an object for the burial of industrial wastewater. Figure 3, $a$ shows a structural map along the top of the formation " $G$ " of the Chokrak sediments, Fig.3, $b$ - a geological profile section along the line 1-1.

Along the top of the sandy formation "G" of the Chokrak horizon, the structure is a strongly elongated brachyanticlinal asymmetric structure due to the disturbance of the southwestern wing by a thrust fault. The southwestern wing is characterized by steep layers (up to $80-90^{\circ}$ ) in the nearcrestal part and in the underthrust of the structure; it sharply flattens out at the transition into the adjacent synclinal fold. The northeastern wing of the structure is a low-angle bedding $\left(20-25^{\circ}\right)$ but it rises sharply up to $50-60^{\circ}$ to the arch.

The total thickness of the Chokrak horizon is $1000-1050 \mathrm{~m}$. Productive layers are those of the "G" formation composed by alternation of quartz sandstones with clay interlayers with total thickness of 280 to $320 \mathrm{~m}$. In total, 22 formations are distinguished in this formation, the thickness of which varies from 3-5 to 30-50 m. Industrial oil deposits are confined to I, II, V, XV, XVII, XIX, XX and XXI sandy formations. The deposits are located at a shallow depth $(360-780 \mathrm{~m})$ and belong to the arched formations type. Due to the heterogeneity of the lithological composition of sandy formations, significant fluctuations in porosity (from 10 to $28 \%$ ) and permeability (from $5 \cdot 10^{-3}$ to $600 \cdot 10^{-3} \mu \mathrm{m}^{2}$ ) are observed. 
$a$

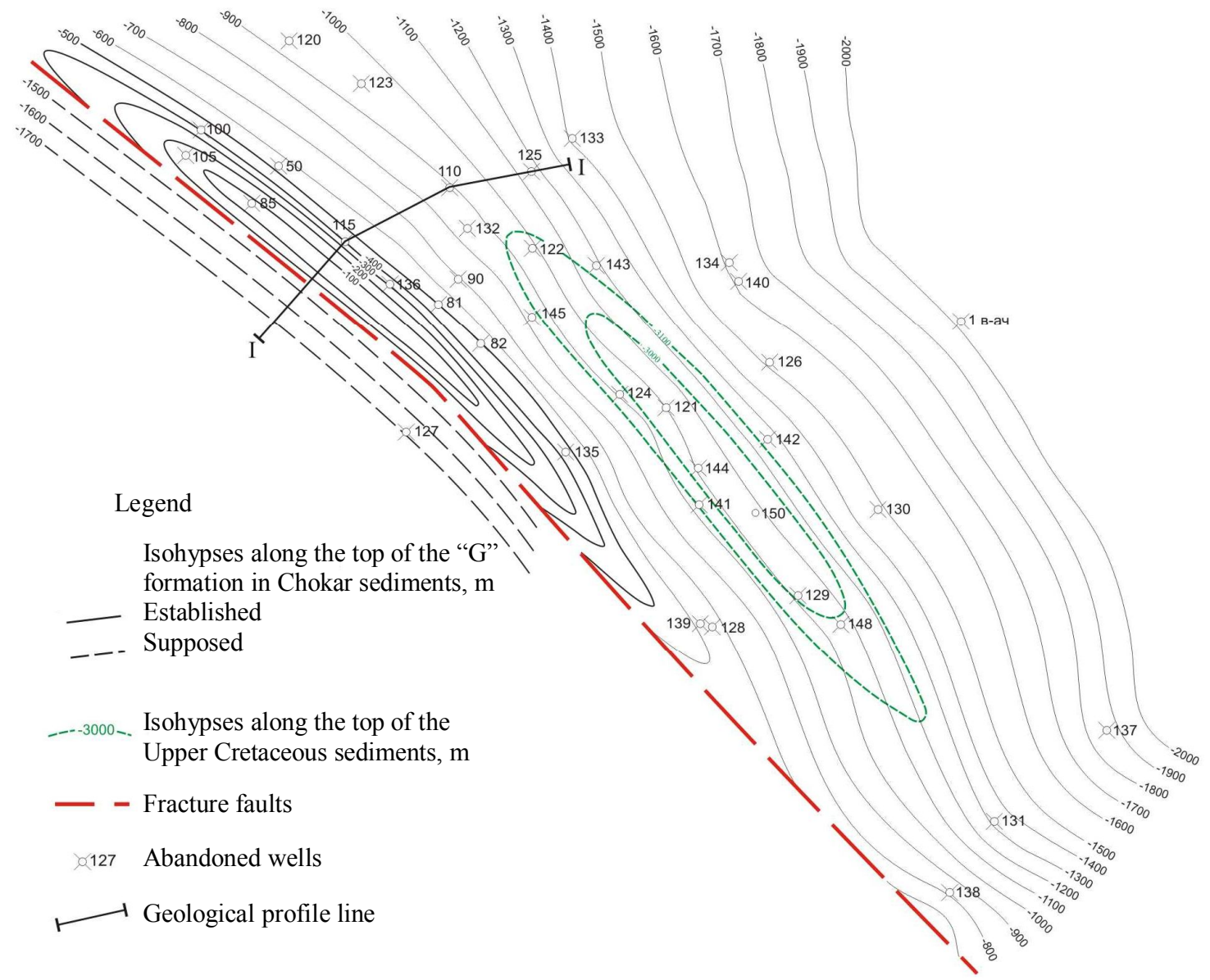

$b$



$\perp \perp$ Well lying on the profile plane
$\perp \perp$ Well reduced on the profile plane

Sandy formations of the Chokrak sediments Tectonic faults

Fig.3. Geological model of DOGCF for Chokrak sediments: $a$-structural map for the surface of the formation " $\mathrm{G}$ " of the Chokrak sediments; $b$ - geological profile section I-I 
The density of oil is $0.867-0.875 \mathrm{~g} / \mathrm{cm}^{3}$; the content of paraffins is $4.45 \%$; the content of resins varies from 6.13 to $8.62 \%$ and of asphaltenes - from 0.73 to $1.85 \%$; the content of light fractions does not exceed $30 \%$. Together with oil, in a number of wells gas was obtained, which had probably been in a dissolved state. The gas is mostly composed of methane (12.1-94.5; the content of heavy hydrocarbons varies from 0.6 to $32.6 \%$, carbon dioxide - from 0.2 to $0.8 \%$, and oxygen is up to $1.6 \%$. Hydrocarbonate-sodium chloride group of " $\mathrm{G}$ " productive formation are slightly mineralized, with their total mineralization increasing with depth.

A US created in a DOGCF is supposed to be operated under conditions of gas regime manifestation. Temperature and pressure conditions of the Chokrak sediments at a depth of $1200 \mathrm{~m}$ suggest a moisture content of $1.5 \mathrm{~kg} / 1000 \mathrm{~m}^{3}$. The volume of condensation water during the extraction period will be $900 \mathrm{~m}^{3}$, and at a daily productivity of up to 14 million $\mathrm{m}^{3}$ it will reach $21 \mathrm{~m}^{3} / \mathrm{day}$. As a result of well testing, it was found that the water content of the Upper Cretaceous sediments largely depends on the reservoir properties of the rocks. The largest inflows of water were obtained in wells that opened the Upper Cretaceous sediments in the crest of the structure; much smaller inflows were obtained in the wells located at its immersion. This phenomenon, by analogy with neighboring fields, can be explained by different cavernosity of the rocks, the degree of which increases towards the fold bend. For this reason, a wide variety of formation water inflows were registered within the field, ranging from $3-4 \mathrm{~m}^{3} / \mathrm{s}$ on the wings of the structure to $345 \mathrm{~m}^{3} / \mathrm{s}$ in the near-front part. Gas is often released with water. The nature of formation water mineralization indicates that, in terms of hydrogeology, the waters of the identified areas are typical for stagnation zones. They are highly mineralized and have almost no bromine and iodine in them (45.55-67.4 and 13.2-20.8 mg/l, respectively).

The groundwater recharge area is located in the southwest of the DOGCF, in the region where the Upper Cretaceous sediments emerge on the soil surface. There is no groundwater discharge area in the DOGCF area. Here, the Upper Cretaceous sediments are submerged to a considerable depth, sheltered with an impermeable cover of Maikop clays, which prevent the overflow of formation waters into the overlying sediments. If migration of of formation waters with poor reservoir properties of limestones to the discharge area is allowed, the discharge area should be sought far to the north and northeast, where the lithological composition of the covering rocks changes and it becomes possible to move water to the overlying horizons.

Thus, the geological prerequisites of the DOGCF area indicate a possible existence of a waterdrive in the Upper Cretaceous layer. However, the strong tectonic disturbance of the folds in the western anticlinal zone and the area of the foothills, where there are longitudinal faults, like thrust faults and overthrusts existing on the entire thickness of the cover, allows us to doubt the existence of a direct hydrodynamic connection of the Upper Cretaceous sediments that compose the folds of the eastern anticlinal zone with the emersion of these sediments on the soil surface.

Based on the results of well drilling, the height of the deposit and the volume of rocks were specified, which amounted to $258 \mathrm{~m}$ and 1190.4 million $\mathrm{m}^{3}$, respectively. To assess the position of the current GWC and porosity characteristics, graphs of the accumulated volume of rocks and recoverable gas reserves were plotted as a function of the deposit height. According to these data, the accumulated gas production $\left(973\right.$ million $\mathrm{m}^{3}$ ) corresponds to the position of the $\mathrm{GWC}$ at $-3117 \mathrm{~m}$.

The surface of the current GWC is assumed horizontal, because the long period of deposit conservation, the head of the edge water, the development of vertically directed cracks and the large difference in the density and viscosity of gas and water contributed to the alignment of the GWC. The calculated mark does not contradict the nature of the watering of the wells operated from the highest levels.

The dynamics of gas, condensate and water extraction is presented in Tables 2 and 3. Analyzing the dynamics of deposit development indicators as a whole, we can draw the following conclusions: the deposit was operated by six wells; gas extraction from wells completely depended on the timing of their commissioning; $68.7 \%$ of the total gas production was extracted from the first well, the next well produced $18.5 \%$; from the two wells, $87.2 \%$ of gas or $73.9 \%$ of active reserves in the deposit were extracted; the four wells commissioned later produced $12.8 \%$ (from 0.4 to $6.3 \%$ per well) or $10.9 \%$ of the reserves (from 0.3 to $5.4 \%$ ). 
Dynamics of gas, condensate and water extraction from the DOGCF

\begin{tabular}{|c|c|c|c|c|c|c|c|c|c|c|c|c|}
\hline \multirow{3}{*}{ Year } & \multicolumn{3}{|c|}{ Extraction } & \multirow{3}{*}{$\underset{\mathrm{g} / \mathrm{m}^{3}}{\mathrm{CGOR},}$} & \multirow{3}{*}{$\begin{array}{l}\mathrm{W}_{\mathrm{g}}, \\
\mathrm{g} / \mathrm{m}^{3}\end{array}$} & \multicolumn{5}{|c|}{ Accumulated production } & \multirow{3}{*}{$\underset{\mathrm{g} / \mathrm{m}^{3}}{\mathrm{CGOR}}$} & \multirow{3}{*}{$\begin{array}{l}\mathrm{H}_{\mathrm{g}}, \\
\mathrm{g} / \mathrm{m}^{3}\end{array}$} \\
\hline & \multirow{2}{*}{$\begin{array}{l}\text { Gas, } \\
\text { million } \\
\mathrm{m}^{3}\end{array}$} & \multirow{2}{*}{$\begin{array}{c}\text { Condensate, } \\
\text { thousand } \\
\text { tons }\end{array}$} & \multirow{2}{*}{$\begin{array}{c}\text { Water, } \\
\text { thousand } \\
\mathrm{m}^{3}\end{array}$} & & & \multirow{2}{*}{$\begin{array}{c}\text { Gas, } \\
\text { million } \mathrm{m}^{3}\end{array}$} & \multicolumn{2}{|c|}{ Condensate } & \multirow{2}{*}{$\begin{array}{l}\text { Gas and } \\
\text { condensate, } \\
\text { million } \mathrm{m}^{3}\end{array}$} & \multirow{2}{*}{$\begin{array}{c}\text { Water, } \\
\text { thousand } \\
\mathrm{m}^{3}\end{array}$} & & \\
\hline & & & & & & & $\begin{array}{l}\text { thousand } \\
\text { tons }\end{array}$ & $\begin{array}{c}\text { million } \\
\mathrm{m}^{3}\end{array}$ & & & & \\
\hline 2009 & 55.0 & 3.5 & 0.0 & 63.9 & 0.0 & 55.0 & 3.5 & 0.4 & 55.4 & 0.0 & 63.9 & 0 \\
\hline 2010 & 80.7 & 5.2 & 0.0 & 64.8 & 0.3 & 135.6 & 8.7 & 1.1 & 136.7 & 0.0 & 64.4 & 0.2 \\
\hline 2011 & 109.4 & 7.1 & 1.8 & 64.8 & 16.1 & 245.1 & 15.8 & 1.9 & 247.0 & 1.8 & 64.6 & 7.3 \\
\hline 2012 & 165.6 & 9.8 & 50.3 & 59.2 & 303.7 & 410.7 & 25.6 & 3.1 & 413.8 & 52.1 & 62.4 & 126.8 \\
\hline 2013 & 190.7 & 8.8 & 36.6 & 46.2 & 191.8 & 601.4 & 34.4 & 4.1 & 605.5 & 88.7 & 57.3 & 147.4 \\
\hline 2014 & 173.8 & 8.6 & 69.9 & 49.2 & 401.9 & 775.2 & 43.0 & 5.2 & 780.4 & 158.5 & 55.5 & 204.5 \\
\hline 2015 & 128.6 & 5.8 & 133.2 & 45.0 & 1035.6 & 903.8 & 48.8 & 5.9 & 909.7 & 291.7 & 54.0 & 322.8 \\
\hline 2016 & 46.4 & 2.4 & 193.2 & 50.9 & 4165.7 & 950.2 & 51.1 & 6.1 & 956.4 & 484.9 & 53.8 & 510.3 \\
\hline 2017 & 16.1 & 0.5 & 137.0 & 32.9 & 8530.5 & 966.3 & 51.7 & 6.2 & 972.5 & 621.9 & 53.5 & 643.6 \\
\hline 2018 & 1.6 & 0.0 & 21.2 & 0.0 & 13054.2 & 967.9 & 51.7 & 6.2 & 974.1 & 643.1 & 53.4 & 664.4 \\
\hline 2019 & 3.9 & 0.103 & 4.5 & 26.4 & 1153.8 & 971.8 & 51.8 & 6.2 & 978.0 & 647.6 & 53.3 & 666.4 \\
\hline
\end{tabular}

Table 3

Dynamics of gas, condensate and water extraction and change of CGR in wells of the DOGCF

\begin{tabular}{|c|c|c|c|c|c|}
\hline \multicolumn{3}{|c|}{ Extraction } & \multirow{2}{*}{$Q_{\text {av.day }}, \mathrm{m}^{3} /$ day } & \multirow{2}{*}{$\mathrm{H}_{\mathrm{g}}, \mathrm{g} / \mathrm{m}^{3}$} & \multirow{2}{*}{$\mathrm{CGR}, \mathrm{g} / \mathrm{m}^{3}$} \\
\hline Gas, million $\mathrm{m}^{3}$ & Condensate, thousand tons & Water,thousand $\mathrm{m}^{3}$ & & & \\
\hline \multicolumn{6}{|c|}{ Well 1} \\
\hline 55.0 & 3.5 & - & 224 & 0 & 63.9 \\
\hline 80.7 & 5.2 & 0.0 & 221 & 0 & 64.8 \\
\hline 99.0 & 6.6 & 1.6 & 271 & 16 & 67.1 \\
\hline 121.3 & 6.6 & 2.8 & 332 & 23 & 54.7 \\
\hline 146.3 & 6.5 & 5.9 & 401 & 40 & 44.7 \\
\hline 84.3 & 3.6 & 29.3 & 231 & 348 & 42.9 \\
\hline 54.8 & 1.8 & 65.7 & 150 & 1199 & 32.2 \\
\hline 17.4 & 0.9 & 94.8 & 48 & 5453 & 49.1 \\
\hline 8.1 & 0.2 & 89.6 & 22 & 11106 & 26.7 \\
\hline 0.7 & - & 11.5 & 2 & 16078 & 0.0 \\
\hline
\end{tabular}

Well 2

\begin{tabular}{c|c|c|c|c|c}
10.4 & 0.4 & 0.2 & 130 & 19 & 42.6 \\
44.3 & 2.5 & 24.0 & 121 & 542 & 56.6 \\
16.9 & 0.6 & 28.5 & 46 & 1690 & 36.1 \\
20.0 & 1.1 & 1.3 & 55 & 66 & 53.8 \\
58.5 & 3.3 & 14.0 & 160 & 240 & 56.1 \\
20.5 & 1.3 & 47.8 & 56 & 2327 & 62.4 \\
7.8 & 0.3 & 46.2 & 21 & 5917 & 38.8 \\
0.9 & - & 9.7 & 2 & 10681 & 0.0
\end{tabular}

Well 3

\begin{tabular}{l|l|c|c|c|c}
21.6 & 1.3 & 2.1 & 108 & 98 & 61.8 \\
16.3 & 1.1 & 15.8 & 45 & 973 & 64.8 \\
4.7 & 0.5 & 8.7 & 13 & 1844 & 108.3 \\
4.6 & 0.1 & 10.3 & 13 & 2221 & 21.5 \\
0.2 & 0.0 & 1.2 & 0 & 6500 & 61.1
\end{tabular}

Note. $Q_{\text {av.day }}$ - average gas flow rate, $\mathrm{m}^{3} /$ day; $\mathrm{H}_{\mathrm{g}}$ - gas humidity, $\mathrm{g} / \mathrm{m}^{3} ; \mathrm{CGR}$ - condensate to gas ratio, $\mathrm{g} / \mathrm{m}^{3}$.

Dynamics of the deposit development indicators was determined by the well operation indicators. With the beginning of the decline in production from the well, the annual production of the deposit began to decrease. The decrease in production was intensive, which was caused by watering of the wells. 
The initial formation pressure, reduced to the middle point of the gas presence stage, was 41.4 $\mathrm{MPa}$, the formation temperature was $135^{\circ} \mathrm{C}$, the temperature gradient was $3.6^{\circ} \mathrm{C} / 100 \mathrm{~m}$. During the development process, the formation pressure dropped down to $26.5 \mathrm{MPa}$. Analysis of the dynamics in the changes of the formation pressure shows that the pressure in the deposit clearly responds to the change in production, indicating that the deposit is a single hydrodynamic reservoir.

In the initial period of development, when gas extraction did not exceed 100 million $\mathrm{m}^{3}$ per year, the rate of pressure drop was insignificant and the specific extraction of formation fluid remained at the same level, varying within 0.3-0.4 million $\mathrm{m}^{3} / \mathrm{MPa}$. During this period, $35.8 \%$ of gas reserves were extracted; there was no formation water in the well product and the formation pressure decreased by $6 \mathrm{MPa}$. The elastic forces of the gas and the aquifer had practically compensated for the drop in formation pressure.

With an increase in annual extraction, the rate of pressure drop increased along with the specific extraction; wells were intensively watered due to the active introduction of edge waters into the deposit (Table 4). Gas energy in the aquifer did not compensate for the drop in formation pressure.

Results of formation pressure measurement in wells of the DOGCF

\begin{tabular}{|c|c|c|c|c|c|c|}
\hline \multirow[b]{2}{*}{ Well № } & \multirow{2}{*}{$\begin{array}{c}\text { Depth of } \\
\text { measurement, } \\
\text { m }\end{array}$} & \multirow{2}{*}{$\begin{array}{l}\text { Point of depth of } \\
\text { measurement, } M\end{array}$} & \multicolumn{3}{|c|}{ Formation pressure, $\mathrm{MPa}$} & \multirow{2}{*}{$\begin{array}{l}\text { Density of the mix- } \\
\text { ture at the } \\
\text { depth of measure- } \\
\text { ment, } \mathrm{g} / \mathrm{m}^{3}\end{array}$} \\
\hline & & & \begin{tabular}{|c|}
$\begin{array}{c}\text { Depth of measure- } \\
\text { ment }\end{array}$ \\
\end{tabular} & Middle of the filter & \begin{tabular}{|c|}
$\begin{array}{c}\text { Middle of the initial gas pres- } \\
\text { ence stage }\end{array}$ \\
\end{tabular} & \\
\hline 1 & 3166 & 3090.7 & 40.25 & 39.95 & 40.41 & 0.287 \\
\hline 2 & 3300 & 3206.4 & 38.7 & 39.53 & 38.64 & 0.102 \\
\hline 3 & 3000 & 2915.3 & 33.95 & 36.56 & 34.53 & 0.257 \\
\hline 4 & 3200 & 3087.6 & 35.96 & 37.02 & 36.01 & 0.081 \\
\hline 5 & 2900 & 2818.7 & 30.58 & 34.88 & 33.87 & 1.027 \\
\hline 6 & 2130 & 2050. & 27.34 & 39.85 & 39.38 & 1.120 \\
\hline
\end{tabular}

It was found that with a decrease in gas production due to watering of the wells, the rate of pressure drop decreased, and its stabilization began. In the last years of the DOGCF development, the formation pressure got established at the level of 26-27 MPa. After production ceased, the formation pressure began to increase, and after a certain period, it restored almost to the initial level. The dominant importance in the deposit regime is the pressure of the water in the aquifer. The data obtained showed that over 30 years of conservation, the pressure in the Upper Cretaceous deposit has been restored almost to the initial value and amounts to 36.8-39.4 MPa.

Conclusion. It has been established that the most capacious reservoirs in the field are the Upper Cretaceous sediments, the industrial oil and gas content of which is associated with sandstones of the Chokrakian horizon of the Neogene and foraminiferal layers of the Paleogene, to which oil deposits are confined, and carbonate sediments of the Upper Cretaceous, including a gas condensate deposit.

After studying the rock samples, a qualitative interpretation of GIW was carried out, the directions of cracks were investigated, which makes it possible to develop a structure of wells with a complex profile (inclined or horizontal) with an increased daily productivity when creating a US.

According to the results of field data, it was found that due to the different cavernosity of rocks, the degree of which increases towards the bend of the fold, the water content of the Upper Cretaceous sediments largely depends on the reservoir properties of the rocks. The largest inflows of water were obtained in wells that opened the Upper Cretaceous sediments in the crest of the structure; much smaller inflows were obtained in wells located at its immersion.

It has been established that watering of the wells leads to a decrease in gas production with a simultaneous decrease in the rate of pressure drop, and then to its stabilization. After the cease of gas production, formation pressure increases and recovers to the initial level. The water pressure of the aquifer becomes dominant in the reservoir mode, which should be taken into account when choosing the structure for the placement of the US operated in the "injection - withdrawal" mode. 
Natural rock masses surrounding the underground storage are practically impermeable at storage the injected products and the rocks composing them are durable, stable, ensuring the reliability of the structure and the vessels being operated (tightness, durability and resource).

Geological indicators and field data of the DOGCF made it possible to determine the possibility of an optimal method for creating a US in a given structure and to evaluate its efficiency during operation.

\section{REFERENCES}

1. Ashikhmin S.G., Kashnikov Yu.A., Yakimov S.Yu. Experimental and theoretical investigations of crack permeability in reservoirs of the Yurubcheno-Tokhomskoye field. Geologiya, geofizika i razrabotka neftyanykh i gazovykh mestorozhdenii. 2013. N 2, p. 36-41 (in Russian).

2. Garaishin A.C., Ruban G.N. The main criteria for selecting a storage formation for the disposal of industrial wastewater from the Karashur underground gas storage. Georesursy. 2010. N 4, p. 26-29 (in Russian).

3. Gasumov R.A. Definition and evaluation of permeability and porosity parameters of clay reservoirs. Nauka. Innovatsii. Tekhnologii. 2018. N 2, p. 115-126 (in Russian).

4. Gasumov R.A. Substantiation of oil and gas saturation thickness and permeability of the lower Maikop clay reservoirs (on the example of fields in the North Caucasus). Neftegazovaya geologiya. Teoriya i praktika. 2018. Vol. 13. N 3, p. 7.

5. Gasumov R.A. The specifics of operating minor deposits (as given by the examples of gas condensate deposits of the Northern Caucasus). Journal of Mining institute. 2016. Vol. 220, p. 556-563. DOI: 10.18454/PMI.2016.4.556

6. Gasumov R.A. Causes of fluid entry absence when developing wells of small deposits (on the example of the KhadumBatalpashinsky horizon). Journal of Mining institute. 2018. Vol. 234, p. 630-636. DOI: 10.31897/PMI.2018.6.630

7. Gracheva O.N., Zinova N.B. Geological prerequisites for the creation of UGS on the base of oil fields in the Russian Federation. Podzemnoe khranenie gaza. Problemy i perspektivy. VNIIGAZ. Moscow, 2003, p. 101-110 (in Russian).

8. Isaeva N.A., Mikhailovskii A.A. Investigation of the maximum allowable pressure of injecting associated gas into the formations-reservoirs of temporary underground storages. Gazovaya promyshlennost. 2011. N 4, p. 55-57 (in Russian).

9. Semenov E.O., Semenov O.G. Study of the lithological composition of clay rocks a new method for assessing the tightness of seals when creating gas storages in aquifers. Nauka i tekhnika v gazovoi promyshlennosti. 2004. N 3-4, p. 18-20 (in Russian).

10. Yamaletdinova A.A., Korobkov G.E. Features of the creation of underground gas storages in a depleted field. Problemy i metody obespecheniya nadezhnosti i bezopasnosti sistem transporta nefti, neftepro-duktov i gaza: Materialy Mezhdunarodnoi nauchno-prakticheskoi konferentsii; UGNTU. Ufa, 2012, p. $90-94$ (in Russian).

11. Dong M., Huang S., Hutchence K. Methane Pressure-Cycling Process With Horizontal Wells for Thin Heavy-Oil Reservoirs. SPE Reservoir Evaluation \& Engineering. 2006. N 88500-PA. DOI: 10.2118/88500-PA

12. Khan G., Rudyk S., Sogaard E. Experimental Studies of Carbon Dioxide Injection for Enhanced oil Recovery Technique; Aalborg University Esbjerg. Esbjerg, 2009, p. 72.

13. Shukla M.K., Klepsch S., Loiskandl W. Miscible Displacement in Porous Media: Theoretical Evaluation. Die Bodenkultur. 1999. Vol. 50/2, p. 93-109.

14. Holland J., Oberwinkler C., Huber M., Zangl G. Utilizing the Value of Continuously Measured Data. SPE Annual Technical Conference and Exhibition. 2004. N 90404. DOI: 10.21818/90404-MS

15. Yang Jian Ping. Chen Wei Zhong, Yang Dian Sen, Yuan Jing. Qiang Numerical determination of strength and deformability of fractured rock mass by FEM modeling. Computers and Geotechnics. 2015. Vol. 64, p. 20-31.

Authors: Ramiz A. Gasumov, Doctor of Engineering Sciences, First Deputy General Director, Priemnaya@Scnipigaz.Ru (JSC «Sevcavnipigaz», Stavropol, Russia), Eldar R. Gasumov, Candidate of Engineering Sciences, Associate Professor (Azerbaijan State Oil Academy, Baku, Azerbaijan), Yulia S. Minchenko, Candidate of Engineering Sciences, Head of Laboratory, MinchenkoYS@scnipigaz.ru (JSC «SevCavNIPIgaz»,Stavropol, Russia).

The paper was received on 20 December, 2019.

The paper was accepted for publication on 11 July, 2020. 